\title{
PENGARUH VIRGIN COCONUT OIL TERHADAP KADAR KOLESTEROL HDL DARAH
}

\author{
${ }^{1}$ Sammy L. Bolang \\ ${ }^{2}$ Djon Wongkar \\ ${ }^{3}$ Ronald I. Ottay
}

\author{
${ }^{1}$ Bagian Gizi Fakultas Kedokteran Universitas Sam Ratulangi Manado \\ ${ }^{2}$ Bagian Anatomi-Histologi Fakultas Kedokteran Universitas Sam Ratulangi Manado \\ ${ }^{3}$ Bagian Ilmu Kedokteran Pencegahan Fakultas Kedokteran Universitas Sam Ratulangi \\ Manado \\ E-mail:alexanderbolang@yahoo.com
}

\begin{abstract}
High Density Lipoprotein Cholesterol (HDL-C) has some protective roles in minimizing cardiovascular diseases. The risks of cardiovascular diseases decrease 2-3\% by increasing $1 \mathrm{mg} / \mathrm{dL}$ of HDL-C. Although the blood levels of triglyceride, total cholesterol, and low density lipoprotein (LDL) are low, these risks are still high if the HDL-C is low. The purpose of this study was to find out whether the consumption of virgin coconut oil (VCO) could increase the HDL-C level. This study used pre and post tests in a randomized control group design. Samples consisted of 39 male students at the ages of $19 \pm 1.6$ years. Nineteen students who were administered VCO $20 \mathrm{ml}$ twice daily (pre-breakfast and pre-dinner) for two weeks belonged to the VCO group, while the others belonged to the control group. The result showed that the mean HDL-C level of the VCO group at day 15 was significantly higher $(P<0.05)$ than at day 1 before VCO administration, with an increase of $10.45 \%$. The mean HDL-C increase of the VCO group at day 15 was also significantly higher $(P<0.05)$ than the difference of the HDL-C level at day 1 and day 15 of the control group. Conclusion: two-week administration of VCO twice daily could increase HDL-C levels.
\end{abstract}

Keywords: virgin coconut oil, High Density Lipoprotein

\begin{abstract}
Abstrak: Kolesterol high density lipoprotein (HDL-C) berperan protektif terhadap penyakit kardiovaskular. Setiap peningkatan kadar HDL-C $1 \mathrm{mg} / \mathrm{dL}$, terjadi penurunan 2-3\% risiko terkena penyakit kardiovaskular. Walaupun kadar trigliserida, kolesterol total, kolesterol low density lipoprotein (LDL-C) rendah, risiko penyakit kardiovaskular tetap tinggi bila kadar kolesterol HDL juga rendah. Penelitian ini bertujuan untuk mendapatkan apakah konsumsi virgin coconut oil (VCO) dapat meningkatkan kadar kolesterol HDL darah. Rancangan penelitian yang digunakan yaitu randomized control group pre-test and post-test. Sampel penelitian sebanyak 39 orang mahasiswa laki-laki dengan usia rata-rata $19 \pm 1,6$ tahun. Sembilan belas mahasiswa mengonsumsi VCO $20 \mathrm{~mL}$ dua kali sehari sebelum makan pagi dan malam selama dua minggu; sampel lainnya menjadi kelompok kontrol. Rerata kadar kolesterol HDL darah setelah mengonsumsi VCO (hari ke-15) lebih tinggi secara bermakna ( $P$ $<0,05$ ) dibandingkan dengan rerata kadar HDL-C darah sebelum mengonsumsi VCO (hari ke-1), dengan peningkatan sebesar 10,45\%. Rerata kenaikan kadar HDL-C darah hari ke-15 setelah mengonsumsi VCO $(\mathrm{p}<0,05)$ lebih tinggi secara bermakna $(P<0,05)$ dibandingkan selisih antara kadar kolesterol HDL darah hari ke-1 dan ke-15 kelompok kontrol. Simpulan: konsumsi VCO selama dua minggu dapat meningkatkan kadar HDL-C.
\end{abstract}

Kata kunci: virgin coconut oil, High Density Lipoprotein 
Penyakit kardiovaskular masih merupakan penyebab kematian utama di banyak negara. Di negara berkembang dari tahun 1990 sampai 2020, angka kematian akibat penyakit kardiovaskular akan meningkat $137 \%$ pada laki-laki dan $120 \%$ pada perempuan, sedangkan di negara maju peningkatannya lebih rendah, yaitu $48 \%$ pada laki-laki dan $29 \%$ pada perempuan. ${ }^{1,2}$

Berdasarkan laporan nasional Riset Kesehatan Dasar di Indonesia tahun 2007, prevalensi penyakit-penyakit kardiovaskular menunjukkan angka yang cukup bermakna. Prevalensi penyakit jantung berdasarkan wawancara sebesar 7,2\% sedangkan cakupan kasus jantung yang sudah didiagnosis oleh tenaga kesehatan sebesar $12,5 \%$. Berdasarkan hasil pengukuran tekanan darah, prevalensi hipertensi pada penduduk 18 tahun ke atas sebesar 31,7\%. Prevalensi stroke ditemukan 8,3 per 1000 penduduk. Berdasarkan Hasil Riset Kesehatan Dasar Propinsi Sulawesi Utara tahun 2007 prevalensi penyakit jantung 8,2\% dan hipertensi $31,2 \%{ }^{3}$

Tingginya insiden penyakit kardiovaskular berhubungan erat dengan profil lipid yaitu tingginya kadar kolesterol total, trigliserida, dan kolesterol low density lipoprotein (LDL-C) dan rendahnya kadar high density lipoprotein (HDL-C). Peran HDL-C sebagai faktor pelindung untuk memerangi penyakit kardiovaskular telah dibuktikan melalui berbagai penelitian. Setiap peningkatan $1 \mathrm{mg} / \mathrm{dL}$ kadar HDL-C, risiko terkena penyakit kardiovaskular berkurang 2-3\%. Walaupun kadar trigliserida, kolesterol total, dan LDL-C rendah, risiko ini tetap tinggi bila kadar HDL-C juga rendah. $^{4-6}$

Konsumsi minyak kelapa dapat memberikan pengaruh yang baik terhadap profil lipid. Minyak kelapa (Cocos nucifera L.) merupakan anggota dari kelompok minyak tropis yang telah digunakan selama berabad-abad dalam diet tradisional masyarakat daerah tropis, seperti kepulauan Polinesia. Populasi ini mengalami lebih sedikit penyakit jantung dan aterosklerosis yang lazim ditemukan di negara barat, sehingga sebagian orang yakin bahwa minyak- minyak tropis seperti minyak kelapa, terutama dalam bentuk alaminya, dapat merupakan bagian dari diet sehat. ${ }^{7,8}$

Virgin Coconut Oil (VCO) dihasilkan dari ekstrak buah kelapa melalui proses tanpa pemanasan atau dengan pemanasan pada suhu rendah. KandunganVCO lebih banyak asam lemak jenuh rantai sedang (atom $\mathrm{C} \leq 12$ ). Gampamole mendapatkan bahwa konsumsi VCO selama dua minggu dengan dosis $2 \times 30 \mathrm{ml}$ sehari dapat meningkatkan kadar HDL-C darah. ${ }^{9}$

\section{METODE PENELITIAN}

Penelitian ini menggunakan Randomized control group pre-test and post-test design dan dilaksanakan di Manado selama bulan Oktober dan November 2010. Sampel penelitian sebanyak 40 orang mahasiswa laki-laki dengan usia rata-rata $19 \pm 1,6$ thn. Dua puluh sampel mengonsumsi $2 \times 20 \mathrm{ml}$ VCO sehari sebelum makan pagi dan malam selama dua minggu (kelompok VCO), dan sampel lainnya tidak mengonsumsi VCO menjadi kelompok kontrol. Kadar HDL-C darah kedua kelompok diperiksa dengan alat Rayto pada hari ke-1 sebelum mengonsumsi VCO dan pada hari ke-15 sesudah mengonsumsi VCO. Satu orang kelompok VCO tidak melanjutkan sebagai subjek penelitian karena mengalami diare setiap kali minum VCO. Analisis data dikerjakan dengan bantuan Statistical Package for Social Sciences (SPSS) ver. 17.

\section{HASIL PENELITIAN}

\section{Karakteristik responden}

Karakteristik responden dapat dilihat pada Tabel 1. Rerata umur responden yaitu 19,4 tahun, dengan umur terendah yaitu 18 tahun dan tertinggi 28 tahun. Rerata berat badan responden yaitu $58,78 \mathrm{~kg}$, dengan berat badan tertinggi yaitu $85,20 \mathrm{~kg}$ dan terendah $42,00 \mathrm{~kg}$. Rerata tinggi badan responden yaitu $166,61 \mathrm{~cm}$, dengan tinggi badan tertinggi yaitu $177,10 \mathrm{~cm}$ dan terendah $155,70 \mathrm{~cm}$. Rerata indeks massa 
tubuh (IMT) responden yaitu $21,12 \mathrm{~kg} / \mathrm{m}^{2}$.

Karakteristik antropometri responden untuk tiap kelompok dapat dilihat pada Tabel 2. Pada kelompok VCO, rerata berat badan $60,21 \mathrm{~kg}$, rerata tinggi badan 166,37 $\mathrm{cm}$, dan rerata IMT $21,72 \mathrm{~kg} / \mathrm{m} 2$. Pada kelompok kontrol, rerata berat badan $57,43 \mathrm{~kg}$, rerata tinggi badan $166,82 \mathrm{~cm}$, dan rerata IMT 20,55 kg/m2. Data pada Tabel 2 menunjukkan bahwa untuk berat badan kelompok VCO lebih besar; untuk tinggi badan masih lebih tinggi pada kelompok kontrol; dan untuk IMT terlihat kelompok VCO lebih besar.

\section{Kadar HDL-C darah}

Kadar HDL-C darah kelompok VCO dapat dilihat pada Tabel 3. Rerata kadar HDL-C darah pada hari ke-1 sebelum mengonsumsi $\mathrm{VCO}$ (VCO-1) 32,26 $\mathrm{mg} / \mathrm{dL}$, dengan nilai tertinggi $42 \mathrm{mg} / \mathrm{dL}$ dan terendah $25 \mathrm{mg} / \mathrm{dL}$. Rerata kadar HDL-C darah pada hari ke-14 sesudah mengonsumsi VCO (VCO-15) 35,63 $\mathrm{mg} / \mathrm{dL}$, dengan nilai tertinggi $45 \mathrm{mg} / \mathrm{dL}$ dan terendah $28 \mathrm{mg} / \mathrm{dL}$. Rerata kenaikan kadar kolesterol HDL darah sesudah mengonsumsi VCO (VCO-15*) 3,37 $\mathrm{mg} / \mathrm{dL}$.

Kadar HDL-C darah kelompok kontrol terangkum pada Tabel 4. Rerata kadar HDL-C darah pada hari ke-1 (K-1) 32,35 $\mathrm{mg} / \mathrm{dL}$, dengan nilai tertinggi $40 \mathrm{mg} / \mathrm{dL}$ dan terendah $24 \mathrm{mg} / \mathrm{dL}$. Rerata kadar HDL-C darah pada hari ke-15 (K-15) $31,90 \mathrm{mg} / \mathrm{dL}$, dengan nilai tertinggi 39 $\mathrm{mg} / \mathrm{dL}$ dan terendah $23 \mathrm{mg} / \mathrm{dL}$. Rerata perubahan kadar HDL-C darah hari ke-15 dibandingkan kadar HDL-C darah hari ke$1\left(\mathrm{~K}-15^{*}\right)-0,45 \mathrm{mg} / \mathrm{dL}$.

\section{Peningkatan kadar HDL-C darah pada kelompok VCO dan kelompok kontrol}

Gambar 1 menunjukkan perbandingan kadar HDL-C darah pada kedua kelompok setelah dua minggu (hari ke-15). Analisis statistik memperlihatkan bahwa pada kelompok VCO rerata kadar HDL-C darah hari ke-15 setelah mengonsumsi VCO (VCO-15) lebih tinggi secara bermakna $(P$ $<0,05)$ dibandingkan rerata kadar HDL-C darah hari ke-1 sebelum mengonsumsi VCO (VCO-1) $(35,63 \mathrm{mg} / \mathrm{dL}$ versus 32,26 $\mathrm{mg} / \mathrm{dL}$ ), dengan peningkatan sebesar $10,45 \%$.

Analisis statistik memperlihatkan bahwa pada kelompok kontrol rerata kadar HDL-C darah hari ke-15 (K-15) tidak berbeda bermakna $(P>0,05)$ dibandingkan dengan rerata kadar HDL-C darah hari ke-1 (K-1) $(31,90 \mathrm{mg} / \mathrm{dL}$ versus $32,35 \mathrm{mg} / \mathrm{dL})$.

Rerata kenaikan kadar HDL-C darah hari ke-15 setelah mengonsumsi VCO (VCO-15*) lebih tinggi secara bermakna $(P<0,05)$ dibandingkan dengan selisih antara kadar HDL-C darah hari ke-15 dan kadar HDL-C darah hari ke-1 kelompok kontrol $\left(\mathrm{K}-15^{*}\right)(3,37 \mathrm{mg} / \mathrm{dL}$ versus $-0,45$ $\mathrm{mg} / \mathrm{dL})$ (Gambar 1).

\section{BAHASAN}

Responden pada kedua kelompok memiliki karakteristik antropometrik yang tidak berbeda secara statistik. Rerata IMT kelompok VCO $21,72 \mathrm{~kg} / \mathrm{m}^{2}$ dan kelompok kontrol $20,53 \mathrm{~kg} / \mathrm{m}^{2}$. Uji-t terhadap kedua rerata ini menghasilkan nilai $P>0,05$, yang berarti rerata IMT kedua kelompok tidak berbeda secara bermakna.

Tabel 1. Karakteristik responden

\begin{tabular}{cllll}
\hline Karakteristik & $N$ & Minimum & Maksimum & Rerata \\
\hline Umur (tahun) & 39 & 18,00 & 28,00 & 19,0256 \\
Berat Badan $(\mathrm{kg})$ & 39 & 42,00 & 85,20 & 58,7833 \\
Tinggi Badan $(\mathrm{cm})$ & 39 & 155,70 & 177,10 & 166,6051 \\
IMT $\left(\mathrm{kg} / \mathrm{m}^{2}\right)$ & 39 & 16,40 & 27,20 & 21,1179 \\
\hline
\end{tabular}


Tabel 2. Karakteristik antropometrik responden tiap kelompok

\begin{tabular}{cllc}
\hline $\begin{array}{c}\text { Karakteristik } \\
\text { antropometrik }\end{array}$ & Kelompok & N & Rerata \\
\hline BB $(\mathrm{kg})$ & VCO & 19 & 60,21 \\
& Kontrol & 20 & 57,43 \\
TB $(\mathrm{cm})$ & VCO & 19 & 166,37 \\
& Kontrol & 20 & 166,82 \\
IMT $\left(\mathrm{kg} / \mathrm{m}^{2}\right)$ & VCO & 19 & 21,72 \\
& Kontrol & 20 & 20,55 \\
\hline
\end{tabular}

Tabel 3. Kadar HDL-C darah pada kelompok VCO

\begin{tabular}{cllll}
\hline $\begin{array}{c}\text { Kadar HDL-C } \\
(\mathrm{mg} / \mathrm{dL})\end{array}$ & $\mathrm{N}$ & Minimum & Maksimum & Rerata \\
\hline VCO-1 & 19 & 25,00 & 42,00 & 32,2632 \\
VCO-15 & 19 & 28,00 & 45,00 & 35,6316 \\
VCO-15* & 19 & 1,00 & 6,00 & 3,3684 \\
\hline
\end{tabular}

Tabel 4. Kadar HDL-C darah pada kelompok kontrol

\begin{tabular}{cllll}
\hline $\begin{array}{c}\text { Kadar HDL-C } \\
(\mathrm{mg} / \mathrm{dL})\end{array}$ & $\mathrm{N}$ & Minimum & Maksimum & Rerata \\
\hline $\mathrm{K}-1$ & 20 & 24,00 & 40,00 & 32,3500 \\
$\mathrm{~K}-15$ & 20 & 23,00 & 39,00 & 31,9000 \\
$\mathrm{~K}-15^{*}$ & 20 & $-3,00$ & 3,00 & $-0,4500$ \\
\hline
\end{tabular}

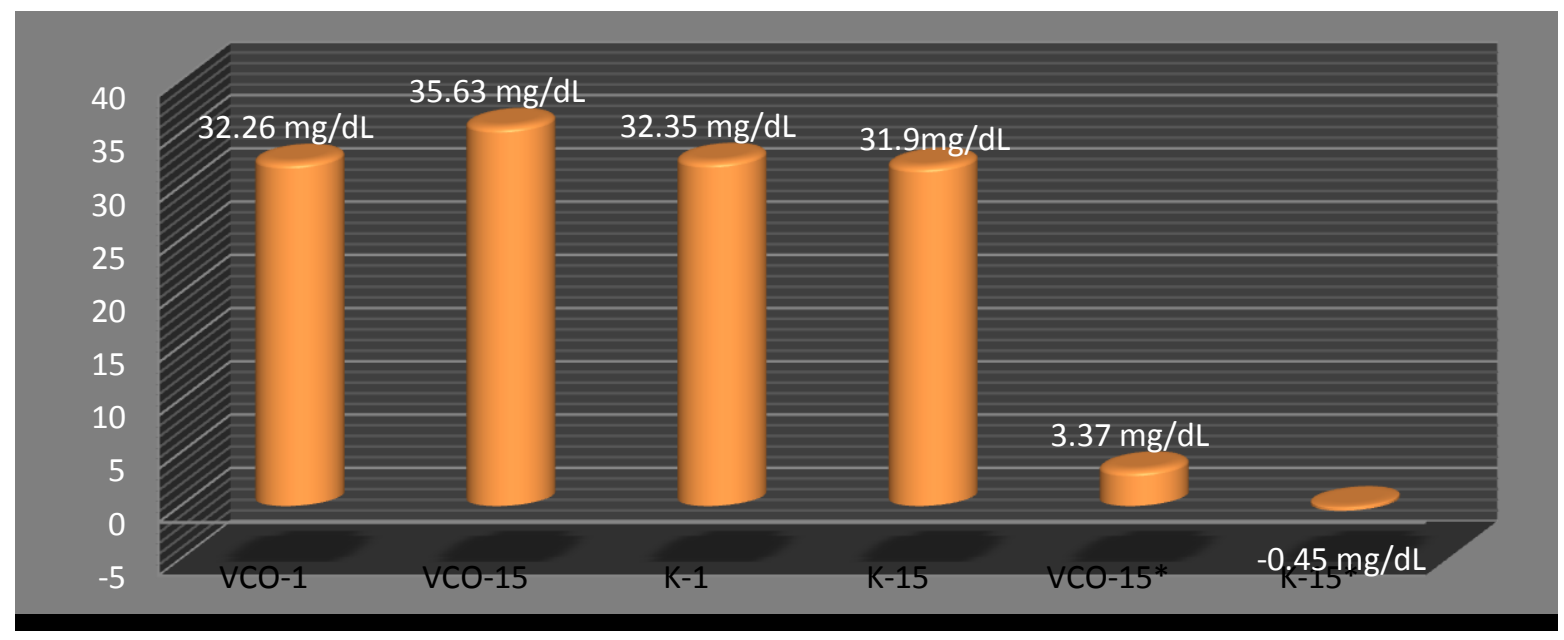

Gambar1. Perbandingan rerata HDL-C hari ke-1 dan hari ke-15 kelompok VCO (VCO-1 dan VCO15) dan kelompok kontrol (K-1 dan K-15), kenaikan kadar HDL-C darah hari ke-15 kelompok VCO (VCO-15*), serta selisih antara kadar HDL-C darah hari ke-15 dan hari ke-1 kelompok kontrol (K$\left.15^{*}\right)$ 
Berdasarkan uji hipotesis dapat disimpulkan terjadi peningkatan kadar HDLC darah pada kelompok VCO setelah mengonsumsi VCO selama dua minggu dibandingkan dengan kelompok kontrol. Hasil ini sesuai dengan hasil penelitian yang dilakukan oleh Gampamole (2007) dengan uji klinik label terbuka, terkontrol, acak dengan rancangan silang yang dimodifikasi untuk membandingkan dua kelompok laki-laki muda yang tinggal seasrama. Kadar HDL-C darah meningkat secara bermakna pada kedua kelompok selama mengonsumsi VCO. Terjadi peningkatan HDL-C sebesar $24,48 \%$ terhadap baseline pada kelompok yang diberi VCO $(P$ $<0,01)$, sedangkan pada kelompok kontrol sebesar $15,28 \%$ terhadap rerata HDL pada akhir fase $1(P<0,05)$. Pada kelompok yang diberi $\mathrm{VCO}$, setelah dua minggu menghentikan VCO terjadi penurunan HDL-C relatif sebesar $-18,28 \%$ dari rerata HDL-C kelompok tersebut pada akhir fase 1. Hal ini menunjukkan bahwa konsumsi VCO merupakan faktor utama yang mempengaruhi peningkatan kadar HDL-C darah. Gampamole juga mendapatkan adanya korelasi yang bermakna secara statistik antara jumlah dosis yang diminum (tingkat kepatuhan) dengan peningkatan kadar HDL-C $(P<0,05)$.

Pada penelitian ini peningkatan kadar HDL-C darah pada kelompok VCO setelah mengonsumsi VCO selama dua minggu sebesar $10,45 \%$, lebih kecil dibandingkan dengan hasil penelitian Gampamole. Dosis VCO yang diberikan pada penelitian ini $2 \mathrm{x}$ $20 \mathrm{~mL}$ sehari, lebih kecil dari yang digunakan Gampamole ${ }^{9}$ yaitu 2 × $30 \mathrm{~mL}$ sehari. Dosis yang dianjurkan Fife (2005) rata-rata 3,5 sendok makan untuk orang dewasa sehari. ${ }^{8}$ Sampel penelitian pada kelompok VCO memiliki rerata berat badan $60,21 \mathrm{~kg}$. Bila menggunakan tabel dosis VCO menurut berat badan yang dianjurkan Fife, ${ }^{8}$ maka dosis $40 \mathrm{ml}$ sehari sesuai dengan anjuran tersebut karena seorang dengan berat badan 45-67 kg (orang dewasa) dianjurkan mengonsumsi VCO 2,5-3 sendok makan atau 37,5-45 ml sehari. Penelitian ini juga membuktikan bahwa kepatuhan minum VCO berkorelasi dengan besarnya peningkatan kadar HDL$\mathrm{C}$ darah $(P<0,05)$.

Peningkatan kadar HDL-C darah oleh karena konsumsi minyak kelapa telah dibuktikan oleh beberapa penelitian terdahulu. Sundram et al menemukan terjadi peningkatan HDL-C sebesar $6,3 \%$ pada orang dewasa dengan kadar lipid darah yang normal ketika mengonsumsi minyak kelapa. ${ }^{10} \mathrm{Ng}$ et al yang memberikan asupan makanan pada 83 orang Malaysia dengan ratio kandungan lemak dari minyak kelapa sebesar $75 \%$ menemukan peningkatan HDL-C darah sebesar 21,4\%. ${ }^{11}$

Nevin dan Rajamohan meneliti pengaruh konsumsi VCO selama 45 hari terhadap sejumlah parameter lipid dan lipoprotein dibandingkan dengan konsumsi minyak kelapa kopra pada tikus SpragueDawley. Hasil penelitian memperlihatkan VCO menurunkan kadar kolesterol total, trigliserida, fosfolipid, kolesterol LDL, dan VLDL, serta meningkatkan HDL-C. Juga disimpulkan bahwa pengaruh VCO terhadap parameter lipid dan lipoprotein tersebut disebabkan oleh kandungan fraksi polifenol yang akan mencegah oksidasi LDL yang dipicu oleh tembaga dan pembentukan karbonil. Polifenol secara biologik aktif sebagai antioksidan yang fisiologik. ${ }^{12}$ Nevin dan Rajamohan juga meneliti lebih lanjut kadar lipid dan lipid peroksida serta aktifitas enzim antioksidan pada kelompok tikus yang diberi VCO dibandingkan dengan kelompok kontrol. Penelitiannya membuktikan bahwa kadar lipid peroksida lebih rendah pada tikus yang diberi VCO sedangkan aktifitas enzim antioksidan dan kemampuan polifenol menangkap radikal bebas lebih tinggi. ${ }^{13}$

Hasil penelitian ini juga sesuai dengan penelitian Surfa (2006) pada tikus Wistar setelah diinduksi aterogenesis, dimana terjadi peningkatan kadar kolesterol HDL serum pada kelompok perlakuan dengan pemberian VCO selama 28 hari. Surfa menyimpulkan bahwa VCO berpengaruh meningkatkan kadar kolesterol serum. ${ }^{14}$ Yuni memberikan VCO pada tikus putih jantan yang aterosklerotik dan membukti- 
kan bahwa VCO meregresi sel busa aterosklerotik dan menurunkan rasio LDL/HDL melalui mekanisme peningkatan kadar HDL-C plasma sehingga jalur transpor balik kolesterol akan teraktivasi. ${ }^{15}$

VCO juga mengandung asam lemak esensial yaitu asam linoleat (omega 6) dan asam linolenat (omega 3) walaupun dalam jumlah yang sedikit. Penelitian epidemiologi membuktikan populasi yang mengonsumsi makanan yang mengandung asam lemak esensial, khususnya omega 3, memiliki insidens penyakit kardiovaskular yang rendah. Omega 3 dapat menurunkan kadar trigliserida serum dan meningkatkan kadar kolesterol HDL darah. ${ }^{16}$

Asam lemak rantai sedang banyak terdapat dalam VCO. Sifat asam lemak ini yang lebih mudah larut dalam air memungkinkannya untuk diserap langsung ke sistem pembuluh darah portal tanpa melalui sistem kilomikron, sehingga akan meningkatkan oksidasi lemak. Asam lemak ini juga berfungsi sebagai ligan peroxisome proliferator-activated receptors (PPAR). Ketiga jenis PPAR $(\alpha, \delta, \gamma)$ akan meningkatkan ekspresi gen dan adenosine triphosphate-binding casette transporter A1 (ABCA-1) yang selanjutnya meningkatkan kadar HDL-C melalui peningkatan transpor balik kolesterol. Hal ini juga didukung oleh Denis dan Massien yang melakukan penelitian dengan memberikan agonis PPAR pada manusia. Sebagai hasil akhir terjadi peningkatan kadar HDL-C melalui perangsangan oksidasi lemak serta peningkatan fungsi carnitine palmitoyl transferase-I (CPT1) dan fatty acid translocator (CD36/FAT). ${ }^{17,18}$

\section{SIMPULAN}

Berdasarkan hasil penelitian dapat disimpulkan bahwa terdapat peningkatan kadar kolesterol HDL darah setelah mengonsumsi VCO selama dua minggu. Hal ini menunjukkan bahwa konsumsi VCO dapat menjadi suatu cara alternatif yang dapat direkomendasikan baik pada pencegahan maupun terapi penyakit kardiovaskular.

\section{DAFTAR PUSTAKA}

1. Capewell S, Ford ES, Bcrot J, Critckler JA, Greenlund KJ, Labarthe DR. Cardiovascular risk factor trend and potential for reducing coronary heart disease mortality. Bulletin the World Health Organization. 2010;88:81-160.

2. Nahar T. Death rate caused by cardiovascular disease [homepage on the Internet]. 2010 [cited 2010 June 12]. Available from: www.antaranews.com.

3. Departemen Kesehatan Republik Indonesia. Laporan Hasil Riset Kesehatan Dasar, 2007.

4. Hopkins PN, Williams RR. Identification and relative weight of cardiovascular risk factors. Cardiol Clin. 1986;4:3-31.

5. Neaton JD, Blackburn H, Jacobs D, Kuller L, Lee DJ, Sherwin R. Serum cholesterol level and mortality findings for men screened in the multiple risk factor intervention trial. Arc Int Med. 1992;152:1490-1500.

6. Wood N. Hepatolipidemic effects of Naringenin in high cornstarch- versus high coconut oil-fed rats. J Med Food. 2004;7:315-9.

7. Prior IA, Davidson F, Salmond CE, Czochanska Z. Cholesterol, coconuts, and diet on Polynesian atolls: a natural experiment: the Pukapuka and Tokelau Island studies. Am J Clin Nutr. 1981;34:1552-61.

8. Fife B. Coconut Oil Miracle. Manila: Penguin Group Inc, 2004.

9. Gampamole DPN. Pengaruh konsumsi virgin coconut oil terhadap profil lipid. Program Studi Ilmu Penyakit Dalam Fakultas Kedokteran Universitas Sam Ratulangi Manado, 2007, tidak dipublikasi.

10. Sundram K, Hayes KC, Siru OH. Dietary palmitic acid results in lower serum cholesterol than does lauricmyristic acid combination in normolipidemic humans. Am J Clin Nutr. 1994;59:841-6.

11. Ng TK, Hassan WK, Lim JB, Lye 
MS, Ishak R. Nonhypercholesterolemic effects of a palm-oil diet in Malaysian volunteers. Am J Clin Nutr. 1991;53:1015S-20S.

12. Nevin KG, Rajamohan T. Beneficial effects of virgin coconut oil on lipid parameters and in vitro LDL oxidation. Clin Biochem. 2004; 37:830-5.

13. Nevin KG, Rajamohan T. Wet and dry extraction of coconut oil: impact on lipid metabolic and antioxidant status in cholesterol coadministered rats. Can J Physiol Pharmacol. 2009; 87(8):610-6.

14. Surfa L. Pengaruh pemberian virgin coconut oil terhadap kadar kolesterol High Density Lipoprotein (HDL) serum tikus Wistar setelah diinduksi aterogenesis [Tesis]. Semarang: Fakultas Kedokteran Universitas
Diponegoro, 2006.

15. Yuni KS. Pengaruh pemberian virgin coconut oil terhadap regresi sel busa dan penurunan rasio LDL/HDL plasma pada tikus putih jantan aterosklerotik [Tesis]. Malang: Fakultas Kedokteran Universitas Muhamadiyah, 2009.

16. Williams MH. Nutrition for Health, Fitness \& Sport. New York: McGraw-Hill, 2007.

17. Berger J, Moller DE. The mechanisms of PPARs. Annu Rev Med. 2002;53:429-35.

18. Dennis L, Massien ScH. Triglyseride: high-density lipoprotein cholesterol effect in healthy subjects administered a peroxisome proliferator actifated receptor $\delta$ agonist. Circulation. 2003;107:2944-8. 